\title{
Impact of biochar coated with magnesium (hydr)oxide on phosphorus leaching from organic and mineral soils
}

\author{
Matthew Riddle $^{1}$ (D) $\cdot$ Lars Bergström $^{1} \cdot$ Frank Schmieder $^{2} \cdot$ Daniel Lundberg $^{3} \cdot$ Leo Condron $^{4} \cdot$ Harald Cederlund $^{3}$
}

Received: 20 June 2018 / Accepted: 13 November 2018 / Published online: 30 November 2018

(C) The Author(s) 2018

\begin{abstract}
Purpose Recent research suggests that Swedish organic arable soils have been under-recognized as a potential source of phosphorus (P) loading to water bodies. The aim of this study was to compare P losses through leaching from organic and highfertility mineral soils. In addition, the effectiveness of a magnesium-salt-coated biochar applied below the topsoil as a mitigation strategy for reducing P losses was evaluated.

Materials and methods Phosphorus leaching was measured from four medium- to high-P arable soils, two Typic Haplosaprists (organic 1 and 2), a Typic Hapludalf (sand), and an unclassified loam textured soil (loam), in a 17-month field study utilizing 90$\mathrm{cm}$-long lysimeters. A magnesium-salt-coated biochar was produced and characterized using X-ray powder diffraction (XPD), scanning electron microscopy with energy-dispersive spectroscopy (SEM-EDS), and X-ray adsorption (XANES) spectroscopy, and its phosphate adsorption capacity was determined at laboratory scale. It was also applied as a $3-\mathrm{cm}$ layer, $27 \mathrm{~cm}$ below the soil surface of the same lysimeters and examined as a mitigation measure to reduce $\mathrm{P}$ leaching.

Results and discussion Total-P loads from the 17-month, unamended lysimeters were in the order of organic $2\left(1.2 \mathrm{~kg} \mathrm{ha}^{-1}\right)>$ organic $1\left(1.0 \mathrm{~kg} \mathrm{ha}^{-1}\right)>$ sand $\left(0.3 \mathrm{~kg} \mathrm{ha}^{-1}\right)>\operatorname{loam}\left(0.2 \mathrm{~kg} \mathrm{ha}^{-1}\right)$. Macropore flow, humic matter competition for sorption sites, and fewer sorption sites likely caused higher P losses from the organic soils. Analysis by XRD and SEM revealed magnesium was primarily deposited as periclase $(\mathrm{MgO})$ on the biochar surface but hydrated to brucite $\left(\mathrm{Mg}(\mathrm{OH})_{2}\right)$ in water. The Langmuir maximum adsorption capacity $\left(Q_{\max }\right)$ of the coated biochar was $65.4 \mathrm{mg} \mathrm{P} \mathrm{g}^{-1}$. Lysimeters produced mixed results, with a $74 \%$ $(P<0.05), 51 \%(\mathrm{NS})$, and $30 \%$ (NS) reduction in phosphate-P from the organic 1, organic 2, and sand, respectively, while $\mathrm{P}$ leaching increased by $230 \%$ (NS) from the loam.

Conclusions The findings of this study indicate that $\mathrm{P}$ leached from organic arable soils can be greater than from mineral soils, and therefore, these organic soils require further investigation into reducing their P losses. Metal-enriched biochar, applied as an adsorptive layer below the topsoil, has the potential to reduce $\mathrm{P}$ losses from medium- to high-P organic soils but appear to be less useful in mineral soils.
\end{abstract}

Keywords Biochar $\cdot$ Leaching $\cdot$ Lysimeter $\cdot$ Phosphorus $\cdot$ Sorption

Responsible editor: Qiaoyun Huang

Electronic supplementary material The online version of this article (https://doi.org/10.1007/s11368-018-2197-7) contains supplementary material, which is available to authorized users.

Matthew Riddle

matthew.riddle@slu.se

1 Water Quality Management Group, Dept. of Soil and Environment, Swedish Univ. of Agricultural Sciences, P.O. Box 7014, 75007 Uppsala, Sweden
2 Plant Nutrition and Soil Fertility Group, Dept. of Soil and Environment, Swedish Univ. of Agricultural Sciences, P.O. Box 7014, 75007 Uppsala, Sweden

3 Department of Molecular Sciences, Swedish Univ. of Agricultural Sciences, P.O. Box 7015, 75007 Uppsala, Sweden

4 Department of Soil and Physical Sciences, Lincoln University, P.O. Box 85084, Lincoln 7647, New Zealand 


\begin{tabular}{|c|c|}
\hline \multicolumn{2}{|c|}{ Abbreviations } \\
\hline $\mathrm{Al}_{\mathrm{ox}}$ & Oxalate-extractable aluminum \\
\hline DPS & Degree of phosphorus saturation \\
\hline DRP & Dissolved reactive phosphorus \\
\hline $\mathrm{Fe}_{\mathrm{ox}}$ & Oxalate-extractable iron \\
\hline ICP-OES & $\begin{array}{l}\text { Inductively coupled plasma } \\
\text { optical emission spectroscopy }\end{array}$ \\
\hline $\mathrm{P}-\mathrm{AL}$ & Ammonium lactate-extractable phosphorus \\
\hline PP & Particulate phosphorus \\
\hline$Q_{\max }$ & Langmuir maximum adsorption capacity \\
\hline SEM & Scanning electron microscopy \\
\hline Total-P & Total phosphorus \\
\hline XANES & $\mathrm{X}$-ray adsorption near-edge structure \\
\hline XPD & X-ray powder diffraction \\
\hline
\end{tabular}

\section{Introduction}

Agricultural intensification has led to an increase in phosphorus (P) loading to many surface water bodies worldwide (McDowell and Sharpley 2001; OECD 2008; Kronvang et al. 2009). In Sweden, agriculture is responsible for up to $40 \%$ of the national anthropogenic P losses to the Baltic Sea (Brandt et al. 2009), with an estimated average of $0.4 \mathrm{~kg}$ $\mathrm{P}$ ha year ${ }^{-1}$ leached from Sweden's agricultural soils (Bergström et al. 2007).

Organic soils represent an underevaluated source of diffuse $\mathrm{P}$ losses. In arable agriculture, organic soils are less common than their mineral soil counterparts, representing $<1 \%$ of potential total arable land worldwide (Blume et al. 2015). However, organic soils are desirable arable soils, especially for root vegetable production, due to the ease of cultivation and harvest. These former wetlands are often cultivated and heavily fertilized, resulting in an accumulation of $\mathrm{P}$ in the surface layers (Shenker et al. 2005; Riddle et al. 2018a). High soil-P concentrations combined with low sorption capacity (Daly et al. 2001) can increase the leaching potential of phosphate, which is often the most common form of $\mathrm{P}$ lost from organic soils (Riddle et al. 2018a).

Transport of $\mathrm{P}$ to surface waters has been related to solute flow within soil, commonly occurring as matrix or preferential flow (Stamm et al. 1998). Preferential flow, due to macropores, is commonly caused by plant roots, worm channels, and soil fissures, and often occurs in clay-textured soils (Jarvis 2007), resulting in pulses of drainage water after heavy rainfall events (Edwards et al. 1992). In peat soils, preferential flow can be caused by drying, resulting in hydrophobicity and shrinkage cracks (Schwärzel et al. 2002). The vertical deposition of organic material during soil development can also present preferential flow pathways (Liu et al. 2016). The reduction in contact with the wider soil matrix caused by this particular flow path (Edwards et al. 1992; Bergström and Shirmohammadi 1999) also reduces contact with potential P sorption sites (Heckrath et al. 1995; Simard et al. 2000). This can result in an increased transfer of applied $P$ from the surface layers to the subsurface, creating vertical leaching of $\mathrm{P}$ (Djodjic et al. 1999).

Results from a Swedish rainfall simulation study (Riddle et al. 2018a) revealed total-P leaching losses from an organic and a mineral soil, from the 0 - to 20 -cm layers, were equivalent to $15 \mathrm{~kg} \mathrm{ha}^{-1}$ and $9.6 \mathrm{~kg} \mathrm{ha}^{-1}$, respectively, after $200 \mathrm{~mm}$ of artificial rainwater was applied over a 2 -week period. These losses are sufficiently high to be of concern to surface water quality and warrant further investigation. The degree of $\mathrm{P}$ saturation (oxalate extraction) (DPS ox ), a measure of potential $P$ release in soils (Beauchemin et al. 1998), was also calculated in that same study and correlated well $(R=0.84)$ with $\mathrm{P}$ leaching from the organic soil, suggesting that the presence of aluminum and iron (hydr)oxides, which are often limited in these soils, is important for controlling losses. This is in agreement with other organic soil research (Litaor et al. 2003; Janardhanan and Daroub 2010; Simmonds et al. 2015). One downside of that study, however, was that there was no possibility to account for re-sorption of $\mathrm{P}$ released, further down in the soil profile, thus limiting any potential full-profile P loss calculations.

The identification of soils that release potentially environmentally damaging P loads to surface waters is an important first step; however, developing effective mitigation strategies is necessary in order to restrict the effects of eutrophication. One such mitigation strategy could be biochar used as a phosphate filter below plant root depth to capture unused mobile $\mathrm{P}$. Biochar, a general term for pyrolyzed organic materials, has been tested in aqueous solutions and in soils for removing phosphate-P, with mixed results (Yao et al. 2012; Parvage et al. 2013; Riddle et al. 2018). Adsorption mechanisms of phosphate on biochar can be complex and often rely on the ash fraction or minerals within the biochar rather than the carbon structure itself (Shepherd et al. 2017; Joseph et al. 2018). In fact, in many cases, biochar has poor natural adsorption properties, due to its negative surface charge (Sizmur et al. 2017) given the levels of $\mathrm{pH}$ in most soils. By incorporating mineral-rich feedstocks (Rawal et al. 2016) or by coating biochar post pyrolysis with a mineral surface, such as those binding phosphate-P naturally in soils, e.g., iron and magnesium (hydr)oxides (Cui et al. 2016; MichálekováRichveisová et al. 2017), the removal can be significantly increased, though actual verification of the performance outside of the laboratory has been limited. A laboratory and 3year lysimeter study investigating the effectiveness and efficiency of a magnetite-coated biochar demonstrated that losses of dissolved reactive $\mathrm{P}(\mathrm{DRP})$ were reduced by $62(P<0.05)$ and $32 \%$ (NS), respectively, from two organic soils (Riddle et al. 2018). However, the laboratory-derived Langmuir maximum adsorption capacity $\left(Q_{\max }\right)$ was only $3.38 \mathrm{mg} \mathrm{P} \mathrm{g}^{-1}$ biochar, which is dwarfed in comparison to values reported 
for biochars coated with magnesium (hydr)oxides, e.g., $239 \mathrm{mg} \mathrm{P} \mathrm{g}^{-1}$ (Fang et al. 2014) and $272 \mathrm{mg} \mathrm{P} \mathrm{g}^{-1}$ (Zhang et al. 2012), suggesting that such magnesium-coated biochars may be more effective in both the laboratory and potentially in field situations.

In this study, $\mathrm{P}$ leaching concentrations and loads from four soils in 80-cm undisturbed soil columns were followed over a 17-month period and used to address the following two objectives: (i) compare P leaching losses between four high-fertility soils, two organic and two mineral soils, and (ii) validate the effectiveness of magnesium (hydr)oxide-coated biochar as a phosphate filter when applied as a 3-cm layer under the topsoil of the same four soils.

\section{Materials and methods}

\subsection{Soil description}

\subsubsection{Organic soils}

Two Histosol soils, organic 1 (Fig. 1a; 59 $13^{\prime} 20.96^{\prime \prime} \mathrm{N}, 14^{\circ}$ $56^{\prime} 36.90^{\prime \prime} \mathrm{E}$ ) and organic 2 (Fig. 1b; 59 $11^{\prime} 30.91^{\prime \prime} \mathrm{N}, 15^{\circ} 35^{\prime}$ $7.83^{\prime \prime}$ E), were collected from South-Central Sweden in the vicinity of the city of Örebro. Both soils were classified as Typic Haplosaprists according to the USDA Natural Resource Conservation Service classification system. The organic soils were chosen based on depth to underlying clay (> $75 \mathrm{~cm}$ ) and a history of intensive arable use. The sites were both reclaimed swampland, with organic 1 initially cleared and drained in the 1980s and organic 2 in the 1940s, with tile drains present at a depth of 80 to $100 \mathrm{~cm}$. The organic soils overlie a gyttja clay. Crops commonly grown at the organic 1 site were spring wheat (Triticum aestivum L.), spring barley (Hordeum vulgare L.), and potatoes (Solanum tuberosum L.) with only mineral fertilizer applied at $\sim 20 \mathrm{~kg} \mathrm{P} \mathrm{ha}^{-1}$ year $^{-1}$, the previous 9 years. The organic 2 site produced wheat and carrots (Daucus carota subsp. sativus), with mineral P fertilizer applied at a rate of $\sim 18 \mathrm{~kg} \mathrm{Pha}^{-1}$ year $^{-1}$.

\subsubsection{Sand}

A loamy sand-textured soil rich in calcium, hereafter referred to as sand (Fig. 1c), classified as a Typic Hapludalf, was collected from a farm outside Kristianstad in Southern Sweden $\left(56^{\circ} 3^{\prime} 38.64^{\prime \prime} \mathrm{N}, 14^{\circ} 3^{\prime} 0.79^{\prime \prime} \mathrm{E}\right), \sim 500 \mathrm{~km}$ south of Örebro. Crops grown included maize (Zea mays subsp. mays L), sugar beet (Beta vulgaris subsp. vulgaris), and spring barley. Large inputs $\left(45 \mathrm{t} \mathrm{ha}^{-1}\right.$ year $^{-1}$ ) of cow slurry (on average $31 \mathrm{~kg}$ $\mathrm{P} \mathrm{ha}^{-1}$ year $^{-1}$ ) had been applied over the previous 40 years, resulting in a P-rich topsoil. The sand overlies a heavy clay at $2 \mathrm{~m}$, and due to a fluctuating water table, it had been tiledrained ( $\sim 80$ to $100 \mathrm{~cm}$ deep) to assist in water removal.

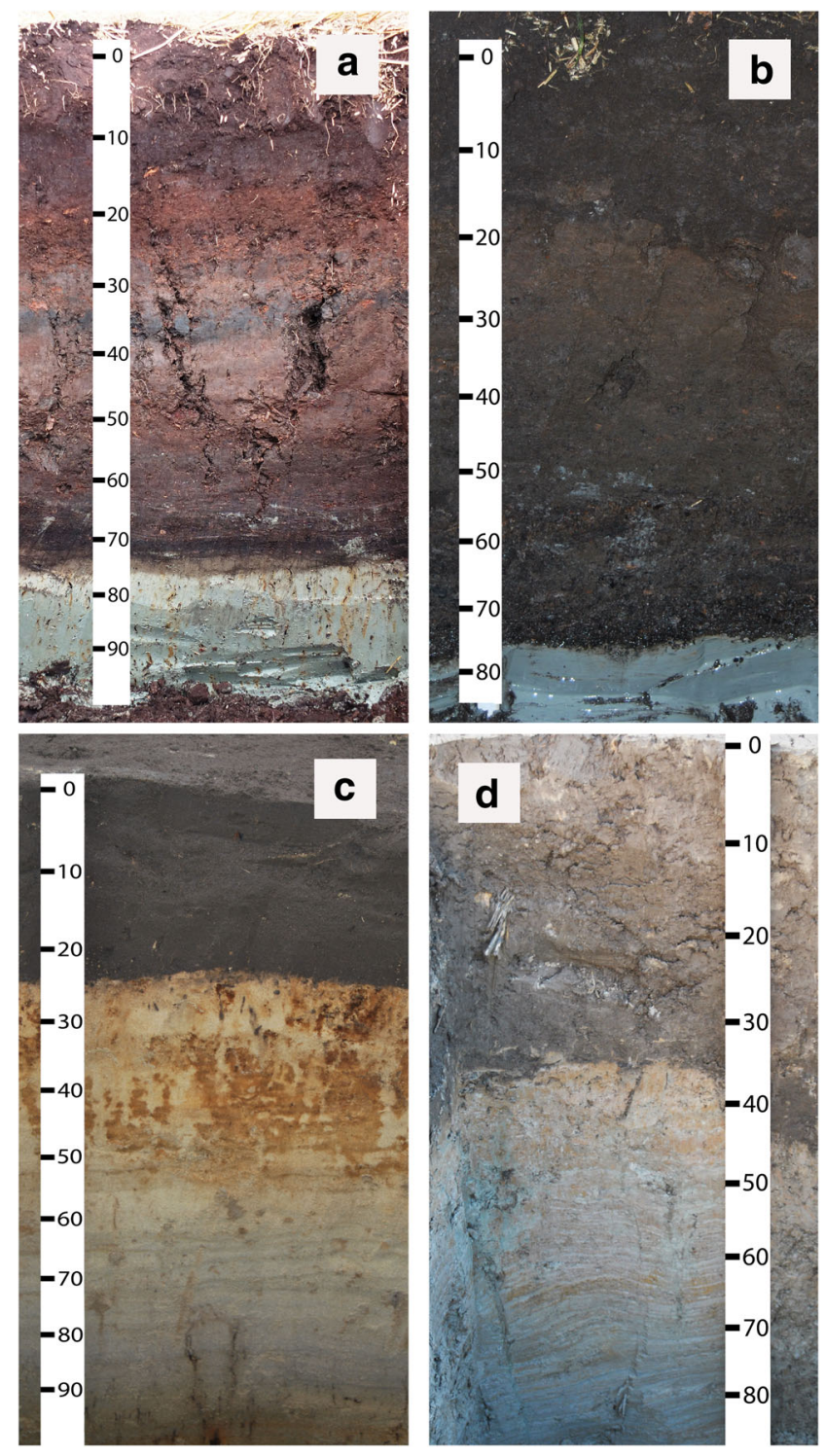

Fig. 1 Soil profile pictures from the four soils. a Organic 1, b organic 2, c sand, d loam

This site is part of a field drainage-water monitoring program returning mean annual $\mathrm{P}$ losses of $1.5 \mathrm{~kg} \mathrm{ha}^{-1}$ year $^{-1}$ (19792010) and maximum loads up to $2.8 \mathrm{~kg} \mathrm{P} \mathrm{ha}^{-1}$ year $^{-1}$ (Data Hosting Agricultural Land 2016). This is considerably higher than the average $\mathrm{P}$ leaching losses of $0.4 \mathrm{~kg} \mathrm{ha}^{-1}$ year $^{-1}$ from typical arable land in Sweden (Bergström et al. 2007). This worst case, high-P-leaching soil was specifically chosen to allow for comparison to the organic soils.

\subsubsection{Loam}

A loam-textured soil, now referred to as loam (Fig. 1d), was collected $300 \mathrm{~m}$ from the sand $\left(56^{\circ} 3^{\prime} 34.85^{\prime \prime} \mathrm{N}, 14^{\circ} 3^{\prime} 16.8^{\prime \prime}\right.$ E) but was not part of the same observation field drainage system. No soil classification was carried out at this site, though soil texture analysis indicated a loam-textured soil 
with an increasing proportion of clay with depth. Crops, inputs of manure, and tile drainage were the same as for the sand.

\subsection{Lysimeter collection}

In October 2013 (organic soils) and November 2014 (mineral soils), undisturbed lysimeters were collected utilizing PVC pipes $(0.9 \mathrm{~m}$ long, $0.295 \mathrm{~m}$ inner diameter) following a tractor-mounted drilling method (Fig. S1, Electronic Supplementary Material - ESM) (Persson and Bergström 1991). Once collected, the six columns from each site (three biochar and three control) were capped and transported to the lysimeter station at the Swedish University of Agricultural Sciences, Uppsala, Sweden (59 49' 3.84" N, $17^{\circ} 39^{\prime} 22.00^{\prime \prime}$ $\mathrm{E})$, where they were kept in a dark, low-temperature environment until lysimeter preparation began, 1-2 months later.

The gravity-drained lysimeters were prepared by first removing any gyttja clay (organic soils only) from the base. Then, a stainless steel mesh $(0.5 \mathrm{~mm})$ was placed under all soils and covered with washed gravel (2 to $5 \mathrm{~mm}$ ) up until $4 \mathrm{~cm}$ from the base, whereby another stainless steel mesh $(0.5 \mathrm{~mm})$ was placed and subsequently covered with a fiberglass lid. The lysimeters were uprighted and the top prepared by removing the top $27 \mathrm{~cm}$ of soil, discarding the next $3 \mathrm{~cm}$ (28 to $30 \mathrm{~cm}$ ), and replacing it with either $3 \mathrm{~cm}$ magnesium (hydr)oxide-coated biochar $(679 \mathrm{~g},<4 \mathrm{~mm})$ equivalent to $99 \mathrm{t} \mathrm{ha}^{-1}$ or $3 \mathrm{~cm}$ of washed 2 to $5 \mathrm{~mm}$ gravel as a control. The $27 \mathrm{~cm}$ of soil was then replaced back into the lysimeter at as close to the same bulk density as possible. The sand and loam were both moist when lysimeters were collected after receiving autumn rainfall. The organic soils were already installed in the lysimeter station from a previous study (Riddle et al. 2018).

Collection of leachate began October 30, 2015. On May 4, 2016, a wheat crop was sown at 550 plants $\mathrm{m}^{2}$. The $P$ fertilizer application rate $\left(22 \mathrm{~kg} \mathrm{P} \mathrm{ha}{ }^{-1}\right.$, as ammonium dihydrogenphosphate, $\left.\left(\mathrm{NH}_{4}\right) \mathrm{H}_{2} \mathrm{PO}_{4}\right)$ was chosen to match maximum yearly manure $\mathrm{P}$ application rates, recommended in Swedish agriculture. Rainfall over the nearly 17 -month period totaled $634 \mathrm{~mm}$. Leachate was sampled when there was enough leachate $(\sim 10 \mathrm{~mm}$ or $700 \mathrm{~mL})$ in most collection bottles which was subsequently analyzed for phosphate-P (Section 2.10). This included 14 sampling occasions between October 2015 and March 2017.

\subsection{Soil analyses}

Soil samples were collected at the same time as lysimeters were taken from each soil for determination of chemical and physical properties. Analysis was carried out on samples collected at 20-cm depth intervals (i.e., at 0-20, 20-40, 40-60, and $60-80 \mathrm{~cm}$, respectively) from the organic soils. However, intervals of $10 \mathrm{~cm}$ were instead used for the sand and loam, as these were also involved in another study. The $10-\mathrm{cm}$ results were averaged to $20-\mathrm{cm}$ intervals to enable comparisons (i.e., $(0-10 \mathrm{~cm}+10-20 \mathrm{~cm}) / 2$ etc.). Due to variation in $\mathrm{pH}$ between soils, samples were extracted using both the ammonium lactate-extractable $\mathrm{P}(\mathrm{P}-\mathrm{AL})$ and Olsen $\mathrm{P}$ methods. The PAL method included extraction with ammonium lactate $(0.1 \mathrm{M})$ and acetic acid $(0.4 \mathrm{M})$ at $\mathrm{pH}=3.75$ and a soil/ solution ratio of 1:20 (P-AL method; Egnér et al. 1960). The extracts were analyzed using inductively coupled plasma spectrometry (ICP-OES; Optima 7300 DV, PerkinElmer, MA, USA). Olsen $P$ was extracted according to the standard method (Olsen and Sommers 1982), whereby soil was extracted in $0.5 \mathrm{M}$ sodium bicarbonate at $\mathrm{pH}=8.5$ and $\mathrm{P}$ content determined using flow injection analysis (FIA star 5000, AN 5246, FOSS, Hillerød, Denmark). Total-P, calcium (Ca), and magnesium $(\mathrm{Mg})$ were extracted with concentrated nitric acid $\left(\mathrm{H}_{3} \mathrm{O}^{+}, \mathrm{NO}_{3}{ }^{-}\right)$on a hotplate, then digested in three stages: first at $60{ }^{\circ} \mathrm{C}$ for $2 \mathrm{~h}$, then at $100{ }^{\circ} \mathrm{C}$ for $1 \mathrm{~h}$, and finally at $130{ }^{\circ} \mathrm{C}$ for $2 \mathrm{~h}$. Analysis was carried out using ICP-OES as above. Total carbon (total-C) was determined by the dry combustion method (LECO 2014) at $1350{ }^{\circ} \mathrm{C}$ using a Leco Tru-Mac CNS 2000 analyzer (LECO, St. Joseph, MI, USA).

Oxalate-extractable iron $\left(\mathrm{Fe}_{\mathrm{ox}}\right)$ and aluminum $\left(\mathrm{Al}_{\mathrm{OX}}\right)$ were extracted following a standard method (ÖNORM L1 1201Austrian Standard) whereby soil samples were ground and mixed at a soil to solution ratio of 1:100, followed by extraction with $0.2 \mathrm{M}$ ammonium oxalate-oxalic acid by shaking for $4 \mathrm{~h}$ in darkness (Schwertmann 1964). Extracts were analyzed using ICP-OES. Soil $\mathrm{pH}$ was determined using dry soil samples mixed with deionized water at a ratio $(w / v)$ of 1:5. Selected chemical and physical results are presented in Table 1.

\subsection{Biochar}

The biochar used in most of the experiments was a commercially available product manufactured in Sweden called "Ecoera." The feedstock was made up of agricultural crop residues which underwent slow pyrolysis at $600^{\circ} \mathrm{C}$. The magnesium (hydr)oxide-coated biochar was produced by thoroughly mixing $700 \mathrm{~g}$ magnesium chloride hexahydrate $\left(\mathrm{MgCl}_{2} \cdot 6 \mathrm{H}_{2} \mathrm{O}\right)$ with $2 \mathrm{~L}$ deionized water in a 10 - $\mathrm{L}$ plastic bucket. Thereafter, $700 \mathrm{~g}(<4 \mathrm{~mm})$ Ecoera biochar was added and mixed. The slurry was divided into two glass dishes and dried at $105^{\circ} \mathrm{C}$ for $24 \mathrm{~h}$. The biochar was mixed twice during the $24 \mathrm{~h}$ to improve drying. Once dried, the biochar was placed into a metal box with a lid and then into a muffle furnace (Nabertherm, model P330, Germany). The temperature was increased to $600{ }^{\circ} \mathrm{C}$ over $1 \mathrm{~h}$, then held constant at $600{ }^{\circ} \mathrm{C}$ for $3 \mathrm{~h}$ in a dinitrogen-gas-enriched environment. The biochar was then left to cool down overnight, after which it was rinsed under $2 \mathrm{~L}$ of water to remove excess magnesium and chloride, and finally dried again for $24 \mathrm{~h}$ at $105^{\circ} \mathrm{C}$. All 
Table 1 Selected physio-chemical properties from the four soils presented in by volume basis for comparison between soils

\begin{tabular}{|c|c|c|c|c|c|c|c|c|c|c|c|c|}
\hline Soil & $\begin{array}{l}\text { Depth } \\
\mathrm{cm}\end{array}$ & $\mathrm{pH}^{\mathrm{a}}$ & $\begin{array}{l}\text { Total-C } \\
\%\end{array}$ & $\begin{array}{l}\text { Bulk } \\
\text { density } \\
\mathrm{g} \mathrm{cm}^{-3}\end{array}$ & $\begin{array}{l}\mathrm{Fe}_{\mathrm{ox}}^{\mathrm{b}} \\
\mathrm{mg} \mathrm{cm}\end{array}$ & $\mathrm{Al}_{\mathrm{ox}}^{\mathrm{b}}$ & Total-Ca & Total-Mg & Total-P & $\mathrm{P}-\mathrm{AL}^{\mathrm{c}}$ & Olsen-P & $\begin{array}{l}\text { DPS }^{\mathrm{d}} \\
\%\end{array}$ \\
\hline \multirow[t]{4}{*}{ Organic 1} & $0-20$ & 5.4 & 44.9 & 0.25 & 1.6 & 0.5 & 8.6 & 0.2 & 0.2 & 0.02 & 0.01 & 15.0 \\
\hline & $20-40$ & 5.7 & 36.6 & 0.32 & 1.8 & 3.0 & 9.2 & 0.3 & 0.3 & 0.01 & 0.00 & 11.3 \\
\hline & $40-60$ & 6.0 & 25.5 & 0.34 & 1.7 & 3.4 & 6.2 & 1.3 & 0.3 & 0.01 & 0.01 & 6.0 \\
\hline & $60-80$ & 5.1 & 34.1 & 0.17 & 1.2 & 1.1 & 2.8 & 0.4 & 0.1 & 0.00 & 0.00 & 2.9 \\
\hline \multirow[t]{4}{*}{ Organic 2} & $0-20$ & 5.1 & 42.9 & 0.30 & 1.1 & 0.6 & 6.3 & 0.3 & 0.4 & 0.05 & 0.02 & $27.9^{\mathrm{e}}$ \\
\hline & $20-40$ & 5.1 & 30.8 & 0.20 & 0.5 & 0.4 & 3.2 & 0.5 & 0.2 & 0.06 & 0.02 & $21.2^{\mathrm{e}}$ \\
\hline & $40-60$ & 5.8 & 30.3 & 0.22 & 1.4 & 0.7 & 4.2 & 0.4 & 0.1 & 0.00 & 0.00 & $7.5^{\mathrm{e}}$ \\
\hline & $60-80$ & 5.5 & 36.5 & 0.42 & 2.4 & 1.1 & 9.1 & 1.5 & 0.2 & 0.03 & 0.01 & $7.5^{\mathrm{e}}$ \\
\hline \multirow[t]{4}{*}{ Sand } & $0-20$ & 7.3 & 2.0 & 1.20 & 2.1 & 1.3 & 3.4 & 1.0 & 1.4 & 0.7 & 0.14 & $92.1^{\mathrm{e}}$ \\
\hline & $20-40$ & 7.5 & 1.0 & 1.20 & 1.5 & 0.8 & 2.5 & 0.7 & 1.1 & 0.5 & 0.10 & $77.3^{\mathrm{e}}$ \\
\hline & $40-60$ & 7.7 & 0.2 & 1.20 & 2.6 & 0.3 & 1.1 & 0.6 & 0.6 & 0.2 & 0.02 & $26.6^{\mathrm{e}}$ \\
\hline & $60-80$ & 7.9 & 0.1 & 1.30 & 0.7 & 0.2 & 1.2 & 0.7 & 0.6 & 0.3 & 0.01 & $49.3^{\mathrm{e}}$ \\
\hline \multirow[t]{4}{*}{ Loam } & $0-20$ & 7.3 & 2.3 & 1.45 & 4.0 & 1.8 & 5.4 & 5.1 & 0.9 & 0.2 & 0.04 & 29.6 \\
\hline & $20-40$ & 7.5 & 1.3 & 1.45 & 4.0 & 1.7 & 5.1 & 5.2 & 0.8 & 0.1 & 0.04 & 27.6 \\
\hline & $40-60$ & 8.0 & 0.1 & 1.50 & 2.1 & 1.8 & 5.5 & 8.3 & 0.7 & 0.1 & 0.00 & 33.9 \\
\hline & $60-80$ & 8.2 & 0.1 & 1.50 & 1.8 & 1.4 & 4.6 & 7.5 & 1.0 & 0.2 & 0.00 & 62.8 \\
\hline
\end{tabular}

${ }^{\mathrm{a}}$ Extracted in water

${ }^{\mathrm{b}}$ Oxalate extractable

${ }^{\mathrm{c}}$ Extractable in ammonium acetate lactate solution

${ }^{\mathrm{d}}$ Degree of phosphorus saturation calculated as $\mathrm{P}_{\mathrm{ox}} /\left[0.5\left(\mathrm{Fe}_{\mathrm{ox}}+\mathrm{Al}_{\mathrm{ox}}\right)\right] \times 100$, where $\mathrm{Fe}_{\mathrm{ox}}$ and $\mathrm{Al}_{\mathrm{ox}}\left(\mathrm{mmol} \mathrm{kg}^{-1}\right)$ are oxalate-extractable $\mathrm{Fe}$ and $\mathrm{Al}$ respectively. DPS values were calculated using $10-\mathrm{cm}$ depth values and therefore using table values $(20 \mathrm{~cm})$ will give differing results

${ }^{\mathrm{e}}$ Data from (Riddle et al. 2018a)

biochar characterization work was performed using a biochar particle diameter $<4 \mathrm{~mm}$. The specific surface area of the biochar was measured according to the Brunauer-EmmettTeller (BET) method (ISO 9277) utilizing $\mathrm{N}_{2}$ gas. Total concentrations of $\mathrm{P}, \mathrm{Ca}, \mathrm{Mg}, \mathrm{Fe}$, potassium $(\mathrm{K})$, sodium $(\mathrm{Na}), \mathrm{Al}$, and sulfur (S) were extracted with concentrated $\mathrm{HNO}_{3}$ and analyzed as for the soil, in Section 2.3. The biochar was then placed as a 3-cm layer (as described in Section 2.2) at $27 \mathrm{~cm}$ below the soil surface, to adsorb any phosphate-P that leached below the typical plant root depth. Control lysimeters had a 3$\mathrm{cm}$ layer of 2-5 $\mathrm{mm}$ washed gravel instead, at the same depth.

\subsection{Scanning electron microscopy with energy-dispersive spectroscopy (SEM-EDS) imaging}

Magnesium (hydr)oxide-coated biochar, as well as both coated and uncoated biochar samples with phosphate adsorbed to them, was applied in powder form to adhesive plates for scanning using a Hitachi Tabletop Microscope TM-1000 equipped with a Bruker Quantax 50 energy dispersion spectroscopy (EDS) analysis system. Phosphate was adsorbed to the biochar by immersing $0.5 \mathrm{~g}$ sieved $(<4 \mathrm{~mm})$ biochar in $30 \mathrm{~mL}$ of
$250 \mathrm{mg} \mathrm{P} \mathrm{L}{ }^{-1}$ potassium phosphate buffer solution at $\mathrm{pH} 6.5$ in 50-mL polypropylene tubes with screw caps. Samples were shaken for $24 \mathrm{~h}$ at $200 \mathrm{rpm}$, rinsed with deionized water for 2 min to remove excess phosphate, and then dried.

\subsection{X-ray powder diffraction (XPD)}

Magnesium (hydr)oxide-coated biochar samples, both with and without P (as prepared in Section 2.5), were analyzed using X-ray powder diffraction to enable identification of the likely magnesium species formed on the biochar surface. The uncoated biochar was also recorded for matters of completeness. The X-ray powder diffraction measurement was performed on an XCalibur Pro, with samples mounted in glass capillaries, using a $2 \theta$ range of $3-117^{\circ}$. The XPD pattern matching procedure utilized the calculated powder patterns (Mercury 3.9, CCDC, Cambridge, UK) of published crystal structures (Inorganic Crystal Structure Database, ICSD v4.0.0, Karlsruhe, Germany), primarily using the $d$ values of listed primary and secondary peaks at Webmineral Mineralogy Database (Webmineral, webmineral.com). No peak-shift correction with regard to the (amorphous) background was performed. 


\subsection{X-ray adsorption near-edge structure spectroscopy (XANES)}

Coated biochar samples $(<4 \mathrm{~mm})$ were immersed in a phosphate solution (as in Section 2.5); however, this time, the $\mathrm{pH}$ of the phosphate buffer solution was not regulated or measured. Phosphorus K-edge XANES fluorescence spectra were collected at beamline 8 of the Synchrotron Light Research Institute (SLRI) in Nakhon Ratchasima, Thailand (Klysubun et al. 2012) following the same procedure as described in Riddle et al. (2018). As there was no readily available magnesium-phosphate standard at the time of fluorescence collection, or in a reference library from the same beam line, a phosphate bound to magnesium and aluminum (hydr)oxides $(\mathrm{Mg} / \mathrm{Al} / \mathrm{P})$ was used instead to confirm what phosphate was adsorbed to on the biochar. The XAS data treatment program Athena in the software package Demeter v.0.9.024 (Ravel and Newville 2005) was utilized for data treatment and analysis, which included energy calibration, merging, and normalization of sample scans also following the procedure outlined in Riddle et al. (2018).

\subsection{Adsorption prestudy}

To determine whether the biochar feedstock or the $\mathrm{Mg}$ coating was most important for phosphate adsorption potential, a prestudy was carried out. Three biochars were chosen, a sugar beet residue biochar pyrolysed at $600{ }^{\circ} \mathrm{C}$; a soft wood pelleted biochar produced by the U.K. Biochar Research Institute (SWP700), pyrolised at $700{ }^{\circ} \mathrm{C}$; and Ecoera as described in Section 2.4. Each biochar was exposed to one of three treatments, (i) a control, i.e., no treatment; (ii) half the magnesium coating concentration as described in Section $2.4(0.5 \mathrm{~g}$ $\mathrm{MgCl}_{2} \mathrm{~g}$ biochar); and (iii) the same magnesium concentration

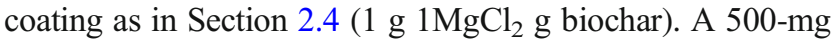
$\mathrm{P} \mathrm{L}^{-1}$ phosphate solution $(0.0162 \mathrm{M})$ (di)hydrogenphosphate was produced, and aliquots of $10 \mathrm{~mL}$ of either phosphate solution or deionized water were added to $0.1 \mathrm{~g}$ dry weight $(0.5-1 \mathrm{~mm})$ biochar, in $15-\mathrm{mL}$ polypropylene tubes with screw caps. Each treatment was replicated five times. Samples were shaken for $24 \mathrm{~h}$ at $200 \mathrm{rpm}$, followed by centrifuging on a Jouan centrifuge (Thermo Fisher Scientific, MA, USA) at $1500 \mathrm{rpm}$ for $10 \mathrm{~min}$. The supernatant $(2 \times 5 \mathrm{~mL}$ samples $)$ was filtered through a $45-\mu \mathrm{m}$ Plastipak syringe filter into a $15-\mathrm{mL}$ scintillation vial and stored at $5{ }^{\circ} \mathrm{C}$ until analyzed.

\subsection{Determination of adsorption isotherms}

A potassium phosphate buffer stock solution containing $1000 \mathrm{mg}$ $\mathrm{P} \mathrm{L}^{-1}(0.0323 \mathrm{M})$ potassium (di)hydrogenphosphate and (di)potassium hydrogenphosphate at $\mathrm{pH}=6.5$ by addition of potassium hydroxide was produced to match the $\mathrm{pH}$ level of the solution used in the SEM and XPD (Sections 2.5 and 2.6) analyses. This stock solution was diluted to seven concentrations $(0$, $25,50,100,250,500$, or $750 \mathrm{mg} \mathrm{P} \mathrm{L}^{-1}$ ). The same procedure as in Section 2.8 was followed with only magnesium-coated or uncoated biochar samples.

The adsorption isotherm of the magnesium-coated biochar was fitted to the Langmuir equation (Eq. (1) using Sigmaplot 12.0 (Systat Software Inc.):

$q_{e=\frac{K \times Q_{\max } \times C_{e}}{1+K \times C_{e}}}$

where $q_{e}$ is the adsorbed amount ( $\mathrm{mg} \mathrm{P} \mathrm{g}^{-1}, C_{e}$ is the equilibrium concentration ( $\left.\mathrm{mg} \mathrm{P} \mathrm{L}^{-1}\right), K$ is a constant related to the binding energy $\left(\mathrm{L} \mathrm{mg}^{-1}\right)$, and $Q_{\max }$ is the Langmuir maximum adsorption capacity ( $\mathrm{mg} \mathrm{P} \mathrm{g}^{-1}$ ).

\subsection{Analysis of $P$ in lysimeter leachate and batch adsorption experiments}

All lysimeter leachate samples were analyzed for total-P, total dissolved P (TDP), and phosphate-P according to the ammonium molybdate spectrometric method (European Committee for Standardization 1996). Total-P was analyzed on unfiltered samples and TDP on filtered samples $(0.2 \mu \mathrm{m}$ pore size, Schleicher \& Schüll $\mathrm{GmbH}$ ). The finer filter size was to capture fine clay particles often recovered from Swedish drainage water (Ulén 2004). Both samples were acidified with $4 \mathrm{M}$ sulfuric acid, $\mathrm{H}_{2} \mathrm{SO}_{4}(\mathrm{aq})$ and digested with a $5 \%(w / w)$ potassium peroxodisulfate, $\mathrm{K}_{2} \mathrm{~S}_{2} \mathrm{O}_{8}(\mathrm{aq})$, following the Bran \& Luebbe Method No. G-175-96 Rev. 2 (modified) and analyzed using a Technicon Autoanalyzer 3 (WI, USA). Phosphate-P was analyzed on filtered, non-digested samples using colorimetry (Gallery Plus, Thermo Fisher Scientific, MA, USA). The difference between total-P and TDP was defined as particulate-P (PP), while the remainder, i.e., total$\mathrm{P}$ minus phosphate-P minus PP was classified as dissolved unreactive-P or residual-P. The residual-P fraction was assumed to be a close estimate for organic-P.

Phosphate-P analysis from the batch adsorption experiment were analyzed using flow injection analysis (FIA star 5000, AN 5246, FOSS, Hillerød, Denmark), according to the FOSS TECATOR AN 5240 ammonium molybdate method.

\subsection{Load calculations}

Calculation of nutrient loads $\left(\mathrm{kg} \mathrm{P} \mathrm{ha}^{-1}\right)$ from lysimeters was carried out by multiplying the geometric mean concentration (mg P L ${ }^{-1}$ ) analyzed from leachate samples by the amount of discharge (mm) and scaling up to 1 ha. This was calculated for each of the replicates, and from this, the mean was determined. 


\subsection{Statistical analysis}

Comparison of the control lysimeter leachate from the four soils was carried out using a one-way ANOVA using Tukey's adjustment, comparing the logged sum of total-P loads from each soil's control treatment $(n=3)$ after the 17month period.

Comparison between biochar and control treatments in the lysimeter study was carried out using log-transformed phosphate data as the response variable, as residuals were not normally distributed. Each soil was analyzed separately using a general linear mixed model with date and treatment as fixed factors, and assessment of their interaction. Pairwise comparisons were made between treatments and dates using Tukey's adjustment for multiple comparisons. Student's $t$ test was used to compare the logged sum of phosphate-P loads between treatments over the study period. The same test was also used to compare cumulative drainage volume differences within each soil treatment All statistical analyses were carried out using the RStudio software package (R Core Team 2014). Differences between treatments were considered significant at $P<0.05$.

\section{Results and discussion}

\subsection{Lysimeter drainage}

A large variation in drainage volumes over the 17 -month period was found between the four soils (Table 2, Fig. 2). This variation may be partially explained by the variability in crop growth resulting in variable plant water uptake (data not shown). However, there was no relationship between the mean volume of drainage collected and the resulting leaching concentrations or loads. Organic 2 had the highest total-P load, but had the lowest drainage volume. The loam lysimeters had on average the highest drainage volumes, but had the

Table 2 Mean total drainage volumes ( $n=3 ; \pm$ standard deviation) from the four soils for both control and biochar treatments

\begin{tabular}{llc}
\hline Site & Treatment & Drainage $(\mathrm{mm})$ \\
\hline Organic 1 & Control & $208.6 \pm 18.8$ \\
Organic 1 & Biochar & $237.2 \pm 3.4$ \\
Organic 2 & Control & $122.8^{\mathrm{a}} \pm 9.3$ \\
Organic 2 & Biochar & $185.8 \pm 40.8$ \\
Sand & Control & $180.5^{\mathrm{a}} \pm 28.0$ \\
Sand & Biochar & $238.2 \pm 21.9$ \\
Loam & Control & $267.3 \pm 65.2$ \\
Loam & Biochar & $276.8 \pm 90.5$ \\
\hline
\end{tabular}

${ }^{\text {a }}$ Indicates statistical difference between the soils respective control and biochar total drainage volumes

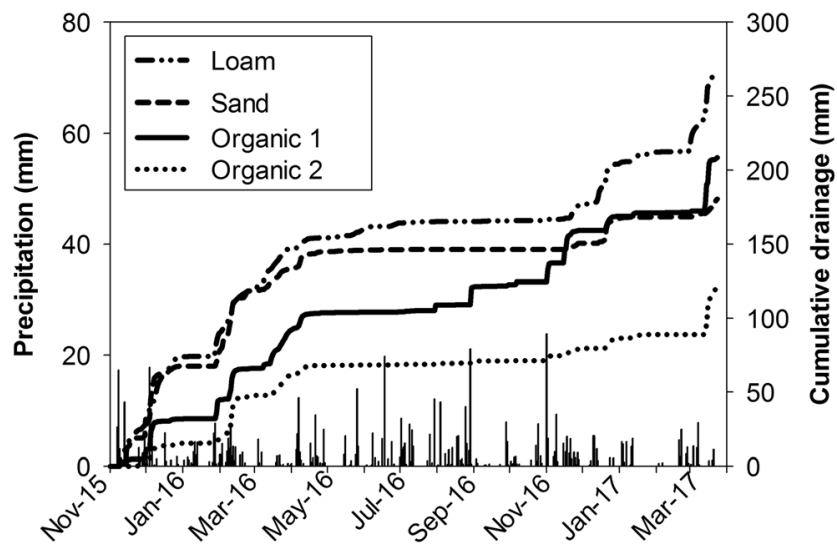

Fig. 2 Precipitation (bars) and mean cumulative drainage (lines) from the four soil control treatments $(n=3)$ during the 17-month lysimeter study. The total precipitation over the study period was $634 \mathrm{~mm}$. Potential preferential flow is indicated by steps in cumulative drainage between August and December 2016, in organic 1 only

lowest leaching loads, which suggests the increased drainage volumes did not reflect increased P loads. A similar observation was also made by Ulén et al. (2016) who found no correlation between drainage flows from fields and total-P leaching.

\subsection{Phosphorus losses from the four soils without biochar}

The proportion of phosphate-, particulate-, and residual-P to total-P in the leachate varied between soils. Between 70 and $90 \%$ was in phosphate-P form from the organic soils, and between 35 and $75 \%$ was from the mineral soils (Fig. 3). The mean phosphate-P concentration from the control treatments was in the order of organic $2\left(0.79 \pm 1.29 \mathrm{mg} \mathrm{L}^{-1}\right)>$ organic $1\left(0.50 \pm 0.98 \mathrm{mg} \mathrm{L}^{-1}\right)>\operatorname{sand}\left(0.39 \pm 1.11 \mathrm{mg} \mathrm{L}^{-1}\right)>$ loam $\left(0.06 \pm 0.12 \mathrm{mg} \mathrm{L}^{-1}\right)$; however, as the standard deviations were large, concentrations can be considered similar. Total-P loads followed the same trend as phosphate-P concentration, with control treatments leaching equivalents of 1.2, 1.0, 0.3, and $0.2 \mathrm{~kg} \mathrm{ha}^{-1}$ (Fig. 3) from the organic 2, organic 1 , sand, and loam, respectively. Less particulate-P was lost from the organic soils (5 to $15 \%$ ) compared to the mineral soils (20 to 55\%). This was likely due to the lower clay content in the organic soils and therefore better soil adhesion due to the abundance of humus (Oades 1984), reducing potential particulate-P losses. The residual-P proportion was similar in leachates from all soils, ranging from 0 to $20 \%$.

\subsection{Variation in P loads between the four soils}

\subsubsection{Organic soils}

The highest total-P leaching loads were $1.2 \mathrm{~kg} \mathrm{P} \mathrm{ha}^{-1}$ from organic 2; however, total-P losses from organic 1, of 
a

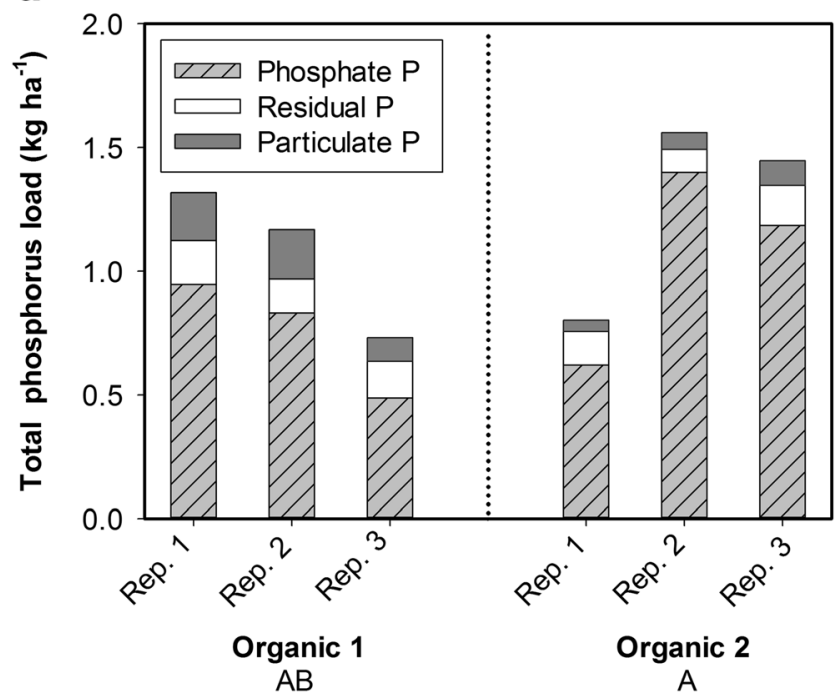

b

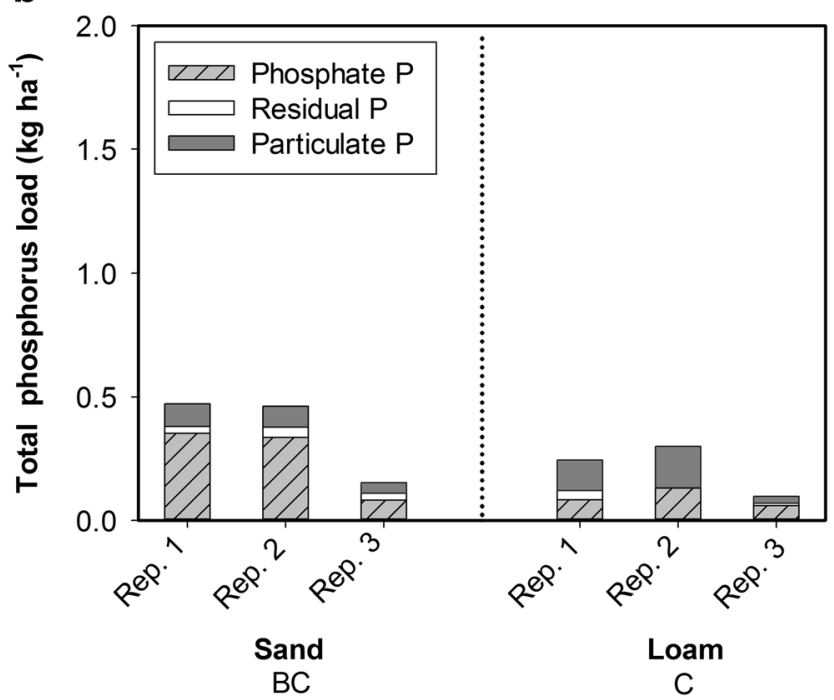

Fig. 3 Lysimeter total-P loads from individual soil replicates over the 17month study, divided into their respective phosphate-P, residual-P, and particulate-P portions: a the organic soils and $\mathbf{b}$ the mineral soils. Different letters under each soil name represent statistical differences in total-P load between the four soils, over the study period $(P<0.05)$

$1.0 \mathrm{~kg} \mathrm{ha}^{-1}$, were not statistically different from those from organic 2. These high losses from both soils occurred even though there were low DPS values in the bottom two layers of the organic soils (Riddle et al. 2018a, Table 1). Low DPS values typically indicate a high potential availability of Pbinding sites. These results imply that these sorption sites did not effectively adsorb $\mathrm{P}$ from the leachate. Potential explanations for this occurrence include preferential flow and humic substances competing for P-sorption sites.

The occurrence of preferential flow can be concluded from soil drainage data between August and November 2016 (Fig. 2). During this period, drainage occurred immediately after heavy rainfall, but only for organic 1 . This is indicated by a stepwise increase in cumulative drainage between August and December 2016 from organic 1, whereas there was no similar occurrence in any of the other three soils. In peat soils, preferential flow has been found to increase with decreasing degree of plant decomposition (Liu et al. 2016), which in the current study occurred below the 20-cm layer in organic 1 , where visual cracks were evident in the profile, but not in organic 2 (Fig. 1a compared to Fig. 1b). These cracks likely resulted in bypass flow, past a portion of the potentially available $\mathrm{P}$ sorption sites (30- to 70 -cm region). These cracks probably occurred due to hydrophobicity of the soil (Schwärzel et al. 2002) or decomposition of vertically deposited organic matter during soil development. When initial soil investigation pits were dug, undecomposed wood fragments were located throughout the profile in organic 1 , but only at the bottom at around $70 \mathrm{~cm}$ of the organic 2 profile, which suggests the macropores in organic 1 may have also been from some decomposed wood pieces, which were not present in the organic 2 profile. Dry soil also causes hydrophobicity (Schwärzel et al. 2002) which enhances this flow type. Multiple macropore scenarios may have occurred simultaneously, accelerating the preferential flow of $\mathrm{P}$ to the bottom of the profile.

The presence of lysimeter side-wall flow in the organic soils is also a potential explanation for this drainage pattern, especially as organic soils are known to shrink and swell with changes in water content, which could cause an artificial flow pathway. However, the cumulative drainage flow pattern from organic 2 (Fig. 2) is very different to that from organic 1, and since the lysimeter extraction technique was the same for both soils, and has been used in previous studies without this problem reported (Bergström et al. 1994; Bergström and Shirmohammadi 1999), the drainage patterns are likely due to soil properties, rather than possible side-wall flow.

Organic 2 had the lowest drainage volumes of all four soils (Fig. 2, Table 2), which suggests that water flow in this soil occurred in more of the potential $680 \mathrm{~mm}$ pore volume than the other soil, and that leaching occurred only when field capacity was reached, or snow melt occurred on saturated or frozen soils in the winter/spring periods. However, it did have the highest mean total-P concentration of all soils, at 12 of the 14 sampling occasions (data not shown). Total-P concentration in leachate was also found to be highest from this soil in a previous rain simulation study (Riddle et al. 2018a). Solute flow was not preferential, but characteristic matrix or "piston flow" (Bergström and Shirmohammadi 1999; Zimmermann et al. 1967) instead (Fig. 2), which should increase contact time with more available sorption sites and therefore decrease P leaching.

The presence of organic carbon in soil solution has, in some cases, been found to increase $\mathrm{P}$ adsorption through complexes of humic substances and iron or aluminum (hydr)oxides. These complexes were reported to have a greater adsorption 
for phosphates than amorphous or crystalline oxides (Gerke and Hermann 1992). However, other studies suggest humic substances can reduce phosphate adsorption by $30 \%$ (Bhatti et al. 1998; Fu et al. 2013) or even up to as much as $500 \%$ (Hua et al. 2008). Competition between humic substances and $P$ for sorption sites (Antelo et al. 2007) is a possible explanation as to why in this study, despite a low DPS in the bottom two soil layers of organic 2 (40 to 60 and 60 to $80 \mathrm{~cm}$ ), and even organic $1, \mathrm{P}$ losses were still so high.

\subsubsection{Sand}

The site where the sand lysimeters were collected had been part of a national drainage water monitoring program since 1973, which has yielded 40 years of drainage and P concentration data to compare to the current lysimeter study results. The annual average total-P loads since monitoring began are $1.5 \pm 0.6 \mathrm{~kg} \mathrm{ha}^{-1}$ (Data Hosting Agricultural Land 2016). Yet, over the same actual time period of the lysimeter study, total-P losses from the monitoring site were $0.34 \mathrm{~kg} \mathrm{ha}^{-1}$. This was, in fact, very close to the 17-month cumulative total-P load of $0.3 \mathrm{~kg} \mathrm{ha}^{-1}$ collected from the lysimeter study. However, precipitation measured at the monitoring site over the 17-month period $(1150 \mathrm{~mm})$ was nearly twice that measured at the lysimeter site $(634 \mathrm{~mm})$ and even higher than the 40-year average at the monitoring site ( $843 \mathrm{~mm}$ during a 17 -month period). Drainage from the monitoring site was $445 \mathrm{~mm}$ compared to the mean $180.5 \mathrm{~mm}$ (Table 2$)$ from the lysimeters $(n=3)$. This could suggest that if rainfall and relative drainage volumes were equal, $\mathrm{P}$ losses from the lysimeters would likely have been much higher. In a previous study, drainage from lysimeters was found to be higher than from adjacent field drainage monitoring sites (Bergström 1987). An explanation for this is that lysimeters collect $100 \%$ of drainage, whereas a proportion of leachate bypasses field drainage systems and forms groundwater instead. This makes it difficult to directly compare results between these two study types.

Threefold more $\mathrm{P}$ was leached from organic 2, than the sand lysimeters. This occurred even though the DPS values calculated for sand (Table 1) were much higher and it contrasts the findings from a previous rainfall simulation study (Riddle et al. 2018a), where leaching losses from the sand equated to $14.2 \mathrm{~kg} \mathrm{ha}^{-1}$ from the 0 - to $40-\mathrm{cm}$ layers, compared to $16.8 \mathrm{~kg} \mathrm{ha}^{-1}$ from organic 2 . The sand DPS values are likely overestimated in the top $40 \mathrm{~cm}$ due to the acidic $\mathrm{P}_{\text {ox }}$ extraction method, and therefore, an overestimation of available P may have occurred (Riddle et al. 2018a). Furthermore, this DPS method did not include $\mathrm{P}$ adsorption to either magnesium- or calcium-bearing minerals. According to Schmieder et al. (2018), (hydroxo)apatite accounts for over half of the soil P in the 60 - to $80-\mathrm{cm}$ layer in this particular soil. This indicates that even though the DPS values were high in the whole sand profile, they were likely overestimated, which explains why leaching losses were low in comparison to those in the organic soils.

\subsubsection{Loam}

Out of the four soils, the loam had the highest cumulative drainage volume (Table 2), but had the lowest total-P leaching losses of $0.2 \mathrm{~kg} \mathrm{ha}^{-1}$. These low losses are a result of the high available sorption capacity of the soil. As with the sand, an overestimation of DPS in this soil is also likely due to high soil $\mathrm{pH}$ and an acid extraction method. However, there is also nearly twice as much $\mathrm{Fe}_{\mathrm{ox}}$, high concentrations of $\mathrm{Al}_{\mathrm{ox}}$, and nine times more magnesium in the loam, than the other soils, which may at least partly represent potential $\mathrm{P}$ sorption sites. The formation of poorly soluble calcium phosphate is also likely important in this soil, due to the high soil $\mathrm{pH}$ (Hopkins and Ellsworth 2005). These soil characteristics resulted in a low mean total-P concentration in leachate of $0.06 \mathrm{mg} \mathrm{L}^{-1}$ and the lowest P loads of the four soils.

\subsection{Magnesium (hydr)oxide-coated biochar as a potential mitigation strategy against phosphate loss}

\subsubsection{Laboratory biochar evaluation}

The process of coating the biochar decreased the surface area by $18 \%$ (Table 3 ), which is commonly found after such biochar treatment processes (Riddle et al. 2018). The magnesium concentration also increased 15-fold, from 5000 to $78,000 \mathrm{mg} \mathrm{kg}^{-1}$ (Table 3 ) after coating.

Scanning electron microscope images of the uncoated biochar revealed mixed particle sizes and forms (Fig. 4b), which is expected due to the diverse agricultural residue feedstock. Energy-dispersive spectroscopy (EDS) analysis of the same sample $(Z \leq 11)$ showed a large concentration of silicon (i.e., quartz, $\mathrm{SiO}_{2}$ ), likely from soil particles mixed into the feedstock when collected (Table S1, ESM). The SEM images of the coated biochar (Fig. 4c, d) showed smaller, irregularshaped structures present on the biochar surface, including some notable needle-like structures. These structures all had high relative amounts of magnesium and chloride (Table S3, ESM). By contrast, the coated biochar immersed in a phosphate solution for $24 \mathrm{~h}$ (Fig. 4e, f) revealed 5-25- $\mu \mathrm{m}$-wide, mainly hexagonal, crystal structures present on the surfaces. The EDS analysis also identified high concentrations of magnesium and phosphorus and lower amounts of iron, in the coated biochar subjected to phosphate (Figs. S5 and S6 and Tables S4 and S5, ESM). The phosphorus appeared to be colocalized with the crystals on the surface of the biochar (Fig. $4 \mathrm{f}$ and Fig. S6, ESM). The XPD analysis of the three samples: uncoated (Fig. S7, ESM), coated (Fig. S8, ESM), and coated subjected to the phosphate solution (Fig. 5) all produced 
Table 3 Chemical and physical analyses of magnesium-coated and uncoated biochar. Values presented are on a dry weight basis

\begin{tabular}{|c|c|c|c|}
\hline \multirow{2}{*}{$\begin{array}{l}\text { Analysis } \\
\text { Specific surface (BET) }\end{array}$} & \multicolumn{2}{|c|}{ Uncoated biochar } & \multirow{2}{*}{$\frac{\text { Mg-coated biochat }}{66.1}$} \\
\hline & $\mathrm{m}^{2} \mathrm{~g}$ & 80.2 & \\
\hline True density & $\mathrm{g} \mathrm{cm}^{3}$ & 1.7 & 1.9 \\
\hline $\mathrm{pH}\left(\mathrm{CaCl}_{2}\right)$ & & 8.5 & 9.7 \\
\hline Ash content $\left(550^{\circ} \mathrm{C}\right)$ & $\%(w / w)$ & 28.3 & 28.4 \\
\hline Total inorganic carbon & $\%(w / w)$ & 0.9 & 0.5 \\
\hline Carbon & $\%(w / w)$ & 59.1 & 60 \\
\hline Hydrogen & $\%(w / w)$ & 1.6 & 1.2 \\
\hline Total nitrogen & $\%(w / w)$ & 2.3 & 1.5 \\
\hline Total sulfur & $\%(w / w)$ & 0.2 & 0.2 \\
\hline Oxygen & $\%(w / w)$ & 0.8 & 9.7 \\
\hline $\mathrm{H} / \mathrm{C}$ ratio & & 0.3 & 0.3 \\
\hline $\mathrm{O} / \mathrm{C}$ ratio & & 0.2 & 0.1 \\
\hline $\mathrm{C} / \mathrm{N}$ ratio & & 26.2 & 40.3 \\
\hline $\mathrm{H} / \mathrm{O}$ ratio & & 0.1 & 0.1 \\
\hline Total phosphorus ${ }^{\mathrm{a}}$ & $\mathrm{mg} \mathrm{kg}^{-1}$ & 8809 & 8798 \\
\hline Total calcium ${ }^{\mathrm{a}}$ & $\mathrm{mg} \mathrm{kg}^{-1}$ & 34,978 & 5522 \\
\hline Total magnesium ${ }^{\mathrm{a}}$ & $\mathrm{mg} \mathrm{kg}^{-1}$ & 5421 & 77,931 \\
\hline Total iron ${ }^{\mathrm{a}}$ & $\mathrm{mg} \mathrm{kg}^{-1}$ & 909 & 8513 \\
\hline Total potassium $^{\mathrm{a}}$ & $\mathrm{mg} \mathrm{kg}^{-1}$ & 23,988 & 3174 \\
\hline Total sodium ${ }^{\mathrm{a}}$ & $\mathrm{mg} \mathrm{kg}^{-1}$ & 256 & 240 \\
\hline Total aluminum $^{\mathrm{a}}$ & $\mathrm{mg} \mathrm{kg}^{-1}$ & 656 & 3872 \\
\hline Total sulfur ${ }^{\mathrm{a}}$ & $\mathrm{mg} \mathrm{kg}^{-1}$ & 1750 & 0 \\
\hline
\end{tabular}

${ }^{a}$ Indicates biochar samples analyzed in the accredited Soil and Plant Laboratory at SLU in Uppsala, Sweden. The remainder at a specialist biochar laboratory, Eurofins, Halsbrücke, Germany

different overall diffraction patterns, though some peaks were identified in more than one sample. All samples had a fairly large background signal, stemming from the amorphous biochar itself, though they also indicated the presence of several crystalline compounds. The most prominent peaks of each of the three biochars were individually matched against reference values until the vast majority of peaks were characterized; several components were identified in each biochar with some overlap between samples. Three minerals were identified in the uncoated biochar (Fig. S7, ESM), with calcite, $\mathrm{CaCO}_{3}$, and quartz, $\mathrm{SiO}_{2}$, being the main minerals, and wüstite, $\mathrm{FeO}$, as a minor phase, in agreement with the SEM-EDS data. The coated biochar (Fig. S8, ESM) was overall less crystalline; nevertheless, in addition to the two strong patterns from the biochar feedstock (calcite and silica), three additional minerals could be identified (periclase, $\mathrm{MgO}$; nesquehonite, $\mathrm{MgCO}_{3}$; and brucite, $\operatorname{Mg}(\mathrm{OH})_{2}$ ), while simultaneously swamping the weak signal from the wüstite. Lastly, the coated biochar subjected to the phosphate solution (Fig. 5) showed a clear diffraction pattern belonging to brucite, $\mathrm{Mg}(\mathrm{OH})_{2}$, with only minor contributions from other phases, which is consistent with the hexagonal crystals seen in the electron micrograph
(Fig. 4f). Together, the results suggest that a conversion from periclase to brucite occurs due to a hydration reaction (Salomão et al. 2014) during exposure to the phosphate solution (Eq. (2), (3)]. This process has been studied in the laboratory at room temperature using distilled water, resulting in $42 \%$ of $\mathrm{MgO}$ being hydrated to $\mathrm{Mg}(\mathrm{OH})_{2}$ after 6 days (del Valle-Zermeño et al. 2012). The rate of this hydration reaction depends on temperature and acidity but occurs spontaneously under wet conditions, which is used at commercial scale in Navarra, Spain, where a low-grade periclase (magnesium oxide) is left in the open for up to 6 months to allow for natural water and air humidity to hydrate it to brucite, $\mathrm{Mg}(\mathrm{OH})_{2}$ (del Valle-Zermeño et al. 2012). It is therefore plausible that the same process would occur under natural soil conditions given a sufficiently humid climate.

$$
\begin{aligned}
& \mathrm{MgO}(s)+\mathrm{H}_{2} \mathrm{O}(l) \rightarrow \mathrm{Mg}(\mathrm{OH})^{+}(a q)+\mathrm{OH}^{-}(a q) \\
& \mathrm{Mg}(\mathrm{OH})^{+}(a q)+\mathrm{OH}^{-}(a q) \rightarrow \mathrm{Mg}(\mathrm{OH})_{2}(\text { s, precipitate })
\end{aligned}
$$

$\mathrm{X}$-ray adsorption near-edge structure (XANES) analysis provided some additional confirmation that phosphate was bound to magnesium ions, even though all types of phosphates share many spectral features (Persson et al. 2019). Additionally, the magnesium standard used included both phosphate bound to magnesium and aluminum (hydr)oxides $(\mathrm{Mg} / \mathrm{Al} / \mathrm{P})$, and therefore, such a structural comparison cannot be used with certainty, to define which oxide phosphate-P was adsorbed to. However, poor spectra matches with the other available standards (Fig. S9C to S9E, ESM) make it possible to at least eliminate other common P sorption possibilities. This includes ferrihydrite (iron(III) oxide hemihydrate, $\mathrm{Fe}_{2} \mathrm{O}_{3} \cdot 1 / 2 \mathrm{H}_{2} \mathrm{O}$ ), (Fig. S9C, ESM) due to no characteristic preedge (Brandes et al. 2007; Ingall et al. 2011) present at around $2150 \mathrm{eV}$ (Riddle et al. 2018). Furthermore, there were no typical hydroxyapatite/calcium phosphate primary $(2157 \mathrm{eV})$ or secondary $(2163 \mathrm{eV})$ peaks (Brandes et al. 2007) on the coated biochar when compared to the hydroxyapatite standard (Fig. S9D, ESM). However, the uncoated biochar does contain these calcium phosphate peaks (Fig. S9A, ESM), which agrees with the large presence of calcite shown by the XRD analysis and indicates $\mathrm{P}$ is mainly bound to calcium carbonate on the uncoated biochar. The main spectra peak of the aluminum hydroxide, $\mathrm{Al}(\mathrm{OH})_{3}$, standard is also much higher than the magnesium-coated biochar spectra peak (Fig. S9E, ESM), which suggests aluminum (hydr)oxide-bound phosphate produces a slightly higher peak intensity and could therefore explain the difference between the magnesium-coated biochar and the $\mathrm{Mg} / \mathrm{Al} / \mathrm{P}$ standard (Fig. S9B, ESM).

Results from the adsorption prestudy indicated that the biochar itself was not important for phosphate adsorption, but instead, the magnesium coating was most crucial (Fig. S10, ESM). This also confirmed the view of Sizmur et al. (2017) 
Fig. 4 Scanning electron micrographs (a and $\mathbf{b})$ of uncoated biochar immersed in phosphate solution (magnifications, $\times 150$ and $\times$ 600); (c and d) coated biochar (magnifications, $\times 150$ and $\times$ 1500); (e and f) coated biochar immersed in phosphate solution (magnifications, $\times 150$ and $\times$ 1500)
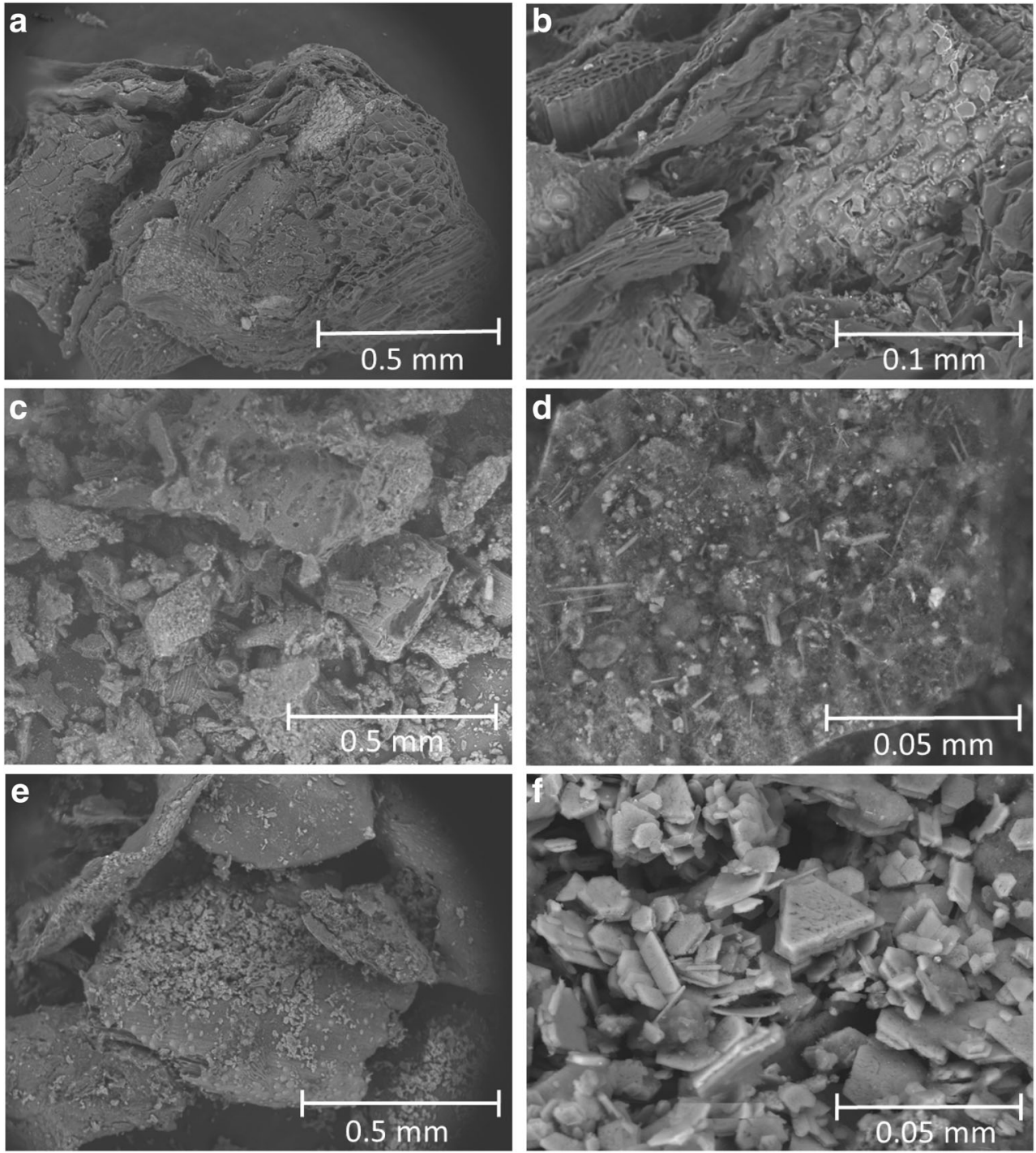

that biochar is only a "porous carbon scaffold upon which metal oxides are precipitated to increase the surface area of the metal oxide". The higher coating concentration was shown to be more effective in adsorbing $\mathrm{P}$ and was therefore used in the rest of the study.

Adsorption isotherm results indicated a large increase in aqueous $\mathrm{P}$ binding capacity, from almost nil in the uncoated

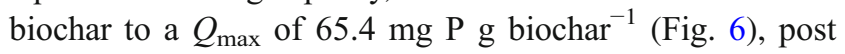
coating. Results were similar to what has been reported by Takaya et al. (2016) with $65 \mathrm{mg} \mathrm{P} \mathrm{g}^{-1}$ and Xu et al. (2017) with $66-120 \mathrm{mg} \mathrm{P} \mathrm{g}^{-1}$ for biochars similarly coated with magnesium salts, but significantly lower than what was reported by Zhang et al. (2012) with $272 \mathrm{mg} \mathrm{P} \mathrm{g}^{-1}$. The high P adsorption in the latter case was likely due to the formation of nanosized $\mathrm{MgO}$ flakes, increasing the potential surface area to bind phosphate.

The mode of $\mathrm{P}$ adsorption to magnesium oxide was out of the scope of this study. However, as the level of $\mathrm{pH}$ at the points of zero charge of both $\mathrm{MgO}$ and $\mathrm{Mg}(\mathrm{OH})_{2}$ are greater than 12 (Kosmulski 2009), their surfaces should be positively charged at naturally occurring soil $\mathrm{pH}$ values and therefore should adsorb P through electrostatic attraction (Zhang et al. 2012). Once this attraction has taken place, adsorption may at least partially occur by forming inner-sphere complexes through sharing an oxygen with the $\mathrm{MgO} / \mathrm{Mg}(\mathrm{OH})_{2}$ mineral surface (Shepherd et al. 2017).

\subsubsection{Effectiveness of biochar as a mitigation strategy}

Comparison of the control and biochar treatment, within each soil, revealed the lysimeters with biochar had higher cumulative drainage volumes for all soils (Table 2). However, only the organic 2 and sand were statistically different from their controls. Comparison of the prior 18-month drainage volumes (Riddle et al. unpublished data) from these same organic 2 lysimeters, before biochar was applied, showed that the same 


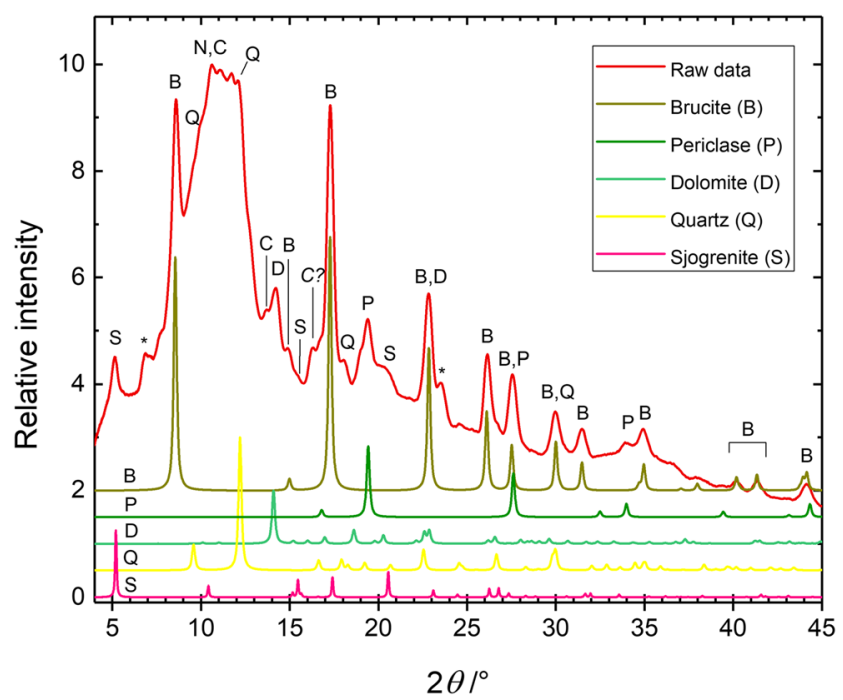

Fig. 5 X-ray powder diffraction of the coated biochar immersed in phosphate solution. The reference spectra of the five most prominent phases are shown, including brucite (B), periclase (P), dolomite (D), quartz (Q), and sjogrenite (S), with cumulative $y$-axis offset (0.4 steps), with each individual spectrum scaled to fit its primary peak. Up to three minor peaks can tentatively be assigned to calcite (C), whereas two peaks were not assigned to any phase (asterisk)

lysimeters (that were later amended with biochar) had consistently higher drainage amounts than the control lysimeters, suggesting the differences in this study are random and that biochar is unlikely to cause an increase in drainage amounts.

The only statistically significant $(P<0.05)$ reduction of cumulative phosphate-P loads occurred between the organic 1, biochar and control treatments (Fig. 7a), where the phosphate-P load was reduced by $74 \%$. Reductions of phosphate-P loads from organic 2 by $51 \%$ and sand by $28 \%$

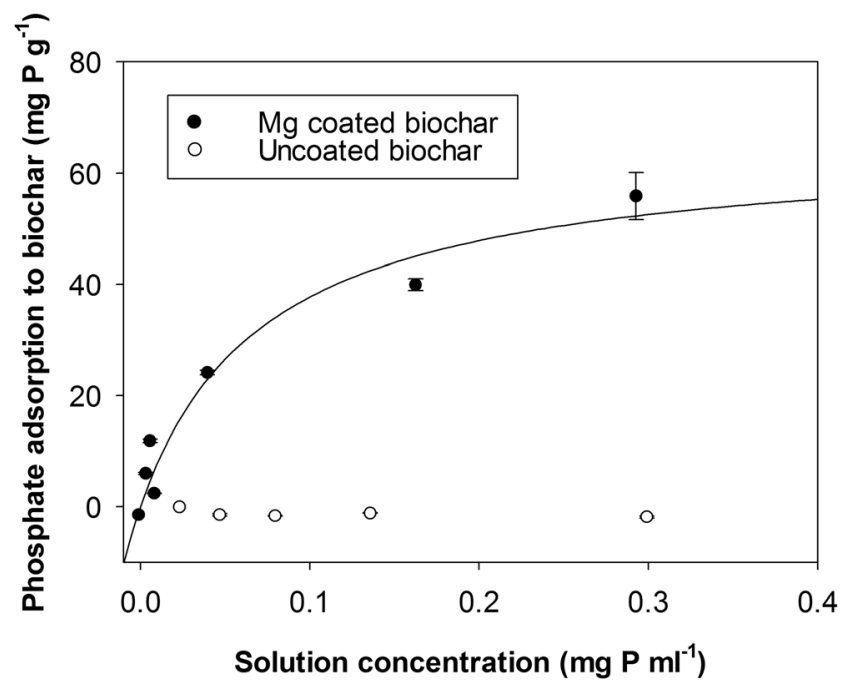

Fig. 6 Phosphate adsorption isotherm of coated biochar compared with uncoated biochar. The Langmuir adsorption equation was fitted to the coated biochar to determine the maximum adsorption capacity $\left(Q_{\max }\right)$, which was $65.4 \mathrm{mg} \mathrm{P} \mathrm{g}^{-1}$ biochar $\left(R^{2}=0.96\right)$. Error bars indicate standard deviation $(n=5)$
(Fig. 7b, c) were not significant. In contrast, phosphate-P loads from the loam increased by $230 \%$ in the biochar treatment compared to the control but due to large variation between replicates, this was not significant either (Fig. 7d). The biochar may have potentially caused this, as the biochar $\mathrm{P}$ content was $8.8 \mathrm{~g} \mathrm{~kg}^{-1}$ (Table 3), or the applied equivalent of $6 \mathrm{mg}$ P per lysimeter $\left(874 \mathrm{~kg} \mathrm{P} \mathrm{ha}^{-1}\right)$. However, this is unlikely as large $\mathrm{P}$ release would have also been noted from the other soils. One hypothesis was that increased erosion due to a structural effect of $\mathrm{Mg}^{2+}$ ions leached out of the biochar on the clay particles (Dontsova and Norton 2002) could have led to increased losses. However, the leaching data showed no increase in particulate-P which would be expected if this was the explanation. Instead, a combination of desorption of $\mathrm{P}$ below the biochar layer and high replicate variability due to the low replicate number $(n=3)$ likely overshadowed the effect of any P sorption/desorption from the biochar in the loam soil.

Of the 14 leachate sampling events, on ten occasions for organic 1 , nil for the organic 2 , and 12 for the sand, did the control lysimeters leach more $\mathrm{P}$ than their respective biochar lysimeters. However, any differences were not statistically significant. The decrease in $\mathrm{P}$ losses between the biochar and control treatments was due to a reduction in phosphateP. Between 40 and 55\% of total-P from the biochar treatment was phosphate-P, compared to 65 to $70 \%$ from the organic 1 control treatment. Slightly higher losses were measured from organic 2, with a phosphate-P of total-P range between 60 and $65 \%$ from the biochar lysimeters and 77 and $90 \%$ from the control.

As there are few previous field studies evaluating biochar as a $\mathrm{P}$ removal strategy, putting our results in context is difficult. However, a 3-year lysimeter study, comparing ironcoated biochar to control lysimeters (Riddle et al. 2018), also reported similar findings. Differences between the biochar and control treatment phosphate-P loads were only found after certain leachate sampling events and only from cumulative loads from the 3-year study for one organic soil (organic 1) but not the other (organic 2), the same as in this current study. This implies that metal-oxide-coated biochar can function successfully as a phosphate filter applied directly below the topsoil, although the effect may only be evident after a longer period of evaluation.

The results here show that the biochar functioned effectively as a P filter in the organic soils only, and even then, it was only statistically different than the control, in organic 1 . Two potential hypotheses could explain these results. Firstly, although only a small amount of $\mathrm{Mg}(\sim 50 \mathrm{~g})$ was added to the soil profile in the biochar layer, it was likely a relatively large contribution to the overall number of $\mathrm{P}$ sorption sites in the organic soils, compared to the mineral soils, which had larger amounts of $\mathrm{Al}, \mathrm{Fe}$ and $\mathrm{Mg}$ (Table 1). The second hypothesis is that the biochar also functioned effectively in the 

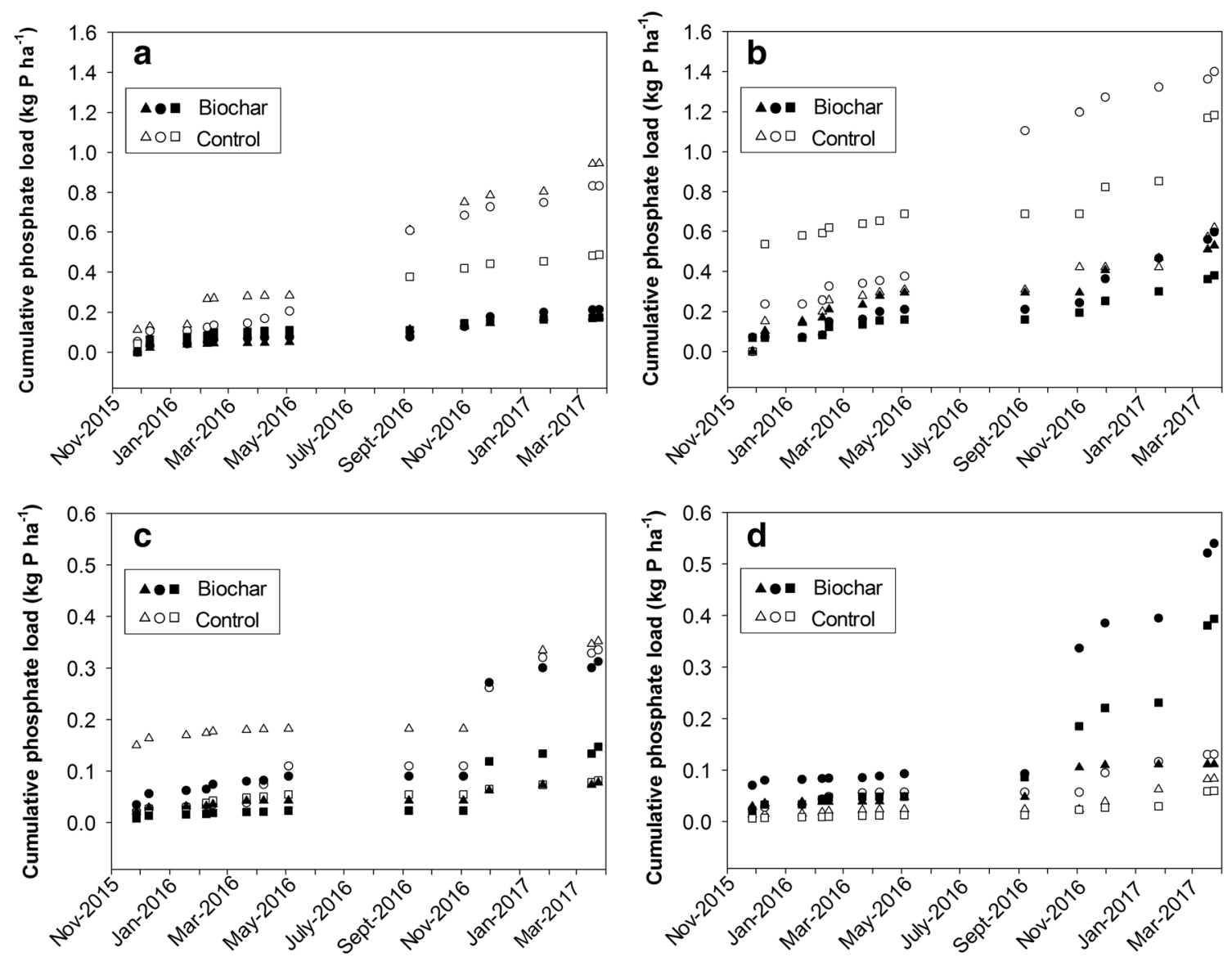

Fig. 7 Cumulative phosphate-P loads from the 17-month lysimeter study containing biochar coated with magnesium (hydr)oxide $(n=3)$ or no biochar $(n=3)$. a Organic 1 , b organic 2, $\mathbf{c}$ sand, and $\mathbf{d}$ loam. Replicates are represented by different shapes within shaded (biochar)

and unshaded (control) markers. Differences between biochar and control treatment were only statistically significant for organic 1 (a). Note the different $y$-axis scales

sand and loam soils; however, larger amounts of P (P-AL and Olsen P, Table 1) are present below the biochar layer in both mineral soils compared to the organic soils, which may have been desorbed, regardless of the effectiveness of the biochar.

The contrast in soil $\mathrm{pH}$ may have also affected the sorption potential of the biochar in the different soils. Previous authors have found a strong influence of $\mathrm{pH}$ on phosphate sorption (Micháleková-Richveisová et al. 2017; Riddle et al. 2018) using iron-coated biochar, where low $\mathrm{pH}$ can increase the adsorption potential of the biochar and high $\mathrm{pH}$ can reduce it. In this study, both low-pH organic soils also had the greatest reduction of $\mathrm{P}$, whereas both mineral soils with a high $\mathrm{pH}$ showed little to no $\mathrm{P}$ reduction with use of the biochar. This may suggest $\mathrm{pH}$ could have an effect on, at least, the magnesium-coated biochar in this study.

\section{Conclusions}

Phosphate-P losses from the four control treatments were in the order of organic $2>$ organic $1>$ sand $>$ loam. Losses were

greater from organic 1 , than the mineral soils, potentially due to preferential flow, causing leachate to by-pass $\mathrm{P}$ sorption sites and potentially higher in both organic soils due to competition between phosphate and humic substances for sorption sites. Less sorption sites overall in the organic soils also likely contributed to the higher $\mathrm{P}$ leaching losses. The results from this study thus support the notion that organic soils have a greater potential than mineral soils for releasing loads of $\mathrm{P}$ to surface waters. However, as differences between lysimeters and field scale leaching can occur, future evaluation through field scale monitoring of $\mathrm{P}$ concentration and load losses would be helpful to better quantify the overall contribution of organic soils.

A magnesium (hydr)oxide-coated biochar proved to be effective in the laboratory, with a maximum adsorption capacity

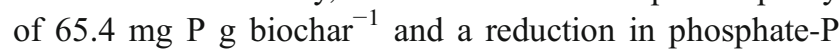
losses from the organic soil lysimeters by 50 to $75 \%$ occurred. However, the biochar did not reduce $\mathrm{P}$ losses from the mineral soils but potentially increased losses from the loam although this was not statistically significant. Existing potential P sorption capacity in the soil was a large determining factor to 
whether the biochar functioned effectively in the soils or not, and is likely the reason for the poorer performance in the mineral soils. Future effective use of magnesium (hydr)oxide-coated biochar as a mitigation strategy will require prior physical and chemical knowledge of the target soil to assess the likelihood of success.

Acknowledgements The authors thank The Swedish Research Council for Environment, Agricultural Sciences and Spatial Planning (Formas), for the funding to carry out this work (project number 19975000). We also appreciate the assistance from the late Göran Johansson in collecting the lysimeters, Gulaim Seisenbaeva for help with the SEM-EDS measurements, Claudia von Brömssen for her statistical expertise (all located at Swedish University of Agricultural Sciences, Uppsala, Sweden), Lars Eriksson (Stockholm University, Stockholm, Sweden) for the help with the XPD measurements, the laboratory staff at the BOKU Institute of SoilResearch, Vienna for the oxalate extractions, Christina Riddle for her graphical layout expertise, and Wantana Klysubun at SLRI in Thailand for her assistance with XANES analysis.

Open Access This article is distributed under the terms of the Creative Commons Attribution 4.0 International License (http:// creativecommons.org/licenses/by/4.0/), which permits unrestricted use, distribution, and reproduction in any medium, provided you give appropriate credit to the original author(s) and the source, provide a link to the Creative Commons license, and indicate if changes were made.

Publisher's Note Springer Nature remains neutral with regard to jurisdictional claims in published maps and institutional affiliations.

\section{References}

Antelo J, Arce F, Avena M, Fiol S, López R, Macías F (2007) Adsorption of a soil humic acid at the surface of goethite and its competitive interaction with phosphate. Geoderma 138:12-19

Beauchemin S, Simard RR, Cluis D (1998) Forms and concentration of phosphorus in drainage water of twenty-seven tile-drained soils. J Environ Qual 27:721-728

Bergström L (1987) Nitrate leaching and drainage from annual and perennial crops in tile-drained plots and lysimeters. J Environ Qual 16: $11-18$

Bergström LF, Shirmohammadi A (1999) Areal extent of preferential flow with profile depth in sand and clay monoliths. J Soil Contam 8:637-651

Bergström L, Jarvis NJ, Stenström J (1994) Pesticide leaching data to validate simulation models for registration purposes. J Environ Sci Health A 29:1073-1104

Bergström L, Djodjic F, Kirchmann H, Nilsson I, Ulén B (2007) Phosphorus from farmland to water-status, flows and preventative measures in a Nordic perspective (Report no. 4/2007), Food 21. Swedish University of Agricultural Sciences, Uppsala

Bhatti JS, Comerford NB, Johnston CT (1998) Influence of oxalate and soil organic matter on sorption and desorption of phosphate onto a spodic horizon. Soil Sci Soc Am J 62:1089-1095

Blume H-P, Brümmer G, Fleige H, Horn R, Kandeler E, Kögel-Knabner I, Kretzschmar R, Stahr K, Wilke BM (2015) Scheffer/ Schachtschabel soil science. Berlin Heidelberg, Germany

Brandes JA, Ingall E, Paterson D (2007) Characterization of minerals and organic phosphorus species in marine sediments using soft X-ray fluorescence spectromicroscopy. Mar Chem 103:250-265
Brandt M, Ejhed H, Rapp L (2009) Nutrient loads to the Swedish marine environment in 2006. (No. Rep. 5995). Swedish Environ. Protect. Agency, Stockholm

Cui X, Dai X, Khan KY, Li T, Yang X, He Z (2016) Removal of phosphate from aqueous solution using magnesium-alginate/chitosan modified biochar microspheres derived from Thalia dealbata. Bioresour Technol 218:1123-1132

Daly K, Jeffrey D, Tunney H (2001) The effect of soil type on phosphorus sorption capacity and desorption dynamics in Irish grassland soils. Soil Use Manag 17:12-20

Data Hosting Agricultural Land (2016) Databas SLU Jordbruksvatten version 2017:2 (accessed 11 June 2017) (In Swedish). SLU, Institute for Soil and Environment. www.jordbruksvatten.slu.se

del Valle-Zermeño R, Chimenos JM, Formosa J, Fernández AI (2012) Hydration of a low-grade magnesium oxide. Lab-scale study. J Chem Technol Biotechnol 87:1702-1708

Djodjic F, Bergström L, Ulén B, Shirmohammadi A (1999) Mode of transport of surface-applied phosphorus-33 through a clay and sandy soil. J Environ Qual 2:1273-1282

Dontsova K, Norton L (2002) Clay dispersion, infiltration, and erosion as influenced by exchangeable Ca and Mg. Soil Sci 167(3):184-193

Edwards WM, Shipitalo MJ, Owens LB, Dick WA (1992) Rainfall intensity affects transport of water and chemicals through macropores in no-till soil. Soil Sci Soc Am J 56:52-58

Egnér H, Riehm H, Domingo W (1960) Untersuchungen über die chemische Bodenanalyse als Grundlage für die Beurteilung des Nährstoffzustandes der Böden: II. Chemische Extraktionsmethoden zur Phosphor- und Kaliumbestimmung (in German) 26:199-215

European Committee for Standardization (1996) Water quality: determination of phosphorus - ammonium molybdate spectrometric method. European Standard EN 1189. Eur. Committee for Standardization, Brussels

Fang C, Zhang T, Li P, Jiang R, Wang Y (2014) Application of magnesium modified corn biochar for phosphorus removal and recovery from swine wastewater. Int J Environ Res Public Health 11:92179237

Fu Z, Wu F, Song K, Lin Y, Bai Y, Zhu Y, Giesy JP (2013) Competitive interaction between soil-derived humic acid and phosphate on goethite. Appl Geochem 36:125-131

Gerke J, Hermann R (1992) Adsorption of orthophosphate to humic-Fecomplexes and to amorphous Fe-oxide. $\mathrm{Z}$ für Pflanzenernähr Bodenkd 155:233-236

Heckrath G, Brookes PC, Poulton P, Goulding KW (1995) Phosphorus leaching from soils containing different phosphorus concentrations in the Broadbalk experiment. J Environ Qual 24:904-910

Hopkins B, Ellsworth J (2005) Phosphorus availability with alkaline/ calcareous soil. West Nutr Manag Conf Vol 6 Salt Lake City UT: $88-93$

Hua Q-X, Li J-Y, Zhou J-M, Wang H-Y, Du C-W, Chen X-Q (2008) Enhancement of phosphorus solubility by humic substances in ferrosols. Pedosphere 18:533-538

Ingall ED, Brandes JA, Diaz JM, de Jonge MD, Paterson D, McNulty I, Elliott WC, Northrup P (2011) Phosphorus K-edge XANES spectroscopy of mineral standards. J Synchrotron Radiat 18:189-197

Janardhanan L, Daroub SH (2010) Phosphorus sorption in organic soils in South Florida. Soil Sci Soc Am J 74:1597

Jarvis NJ (2007) A review of non-equilibrium water flow and solute transport in soil macropores: principles, controlling factors and consequences for water quality. Eur J Soil Sci 58:523-546

Joseph S, Kammann CI, Shepherd JG, Conte P, Schmidt H-P, Hagemann N, Rich AM, Marjo CE, Allen J, Munroe P, Mitchell DRG, Donne S, Spokas K, Graber ER (2018) Microstructural and associated chemical changes during the composting of a high temperature biochar: mechanisms for nitrate, phosphate and other nutrient retention and release. Sci Total Environ 618:1210-1223 
Klysubun W, Sombunchoo P, Deenan W, Kongmark C (2012) Performance and status of beamline BL8 at SLRI for X-ray absorption spectroscopy. J Synchrotron Radiat 19:930-936

Kosmulski M (2009) Surface charging and points of zero charge. Taylor \& Francis Group, Boca Raton, FL

Kronvang B, Rubæk GH, Heckrath G (2009) International phosphorus workshop: diffuse phosphorus loss to surface water bodies - risk assessment, mitigation options, and ecological effects in river basins. J Environ Qual 38:1924-1929

LECO (2014) Carbon/nitrogen in soil and plant tissue http://www. lecochina.cn/home/index/downfile/dir/CNPSTruMac/name/ 8TRUMAC_CARBON_NITROGEN_SOIL_PLANT_TISSUE_ 203-821-437 (accessed 20 Sept 2017)

Litaor MI, Reichmann O, Belzer M, Auerswald K, Nishri A, Shenker M (2003) Spatial analysis of phosphorus sorption capacity in a semiarid altered wetland. J Environ Qual 32:335-343

Liu H, Janssen M, Lennartz B (2016) Changes in flow and transport patterns in fen peat following soil degradation: flow and transport patterns in fen peat. Eur J Soil Sci 67:763-772

McDowell RW, Sharpley AN (2001) Approximating phosphorus release from soils to surface runoff and subsurface drainage. J Environ Qual 30:508-520

Micháleková-Richveisová B, Frišták V, Pipiška M, Ďuriška L, MorenoJimenez E, Soja G (2017) Iron-impregnated biochars as effective phosphate sorption materials. Environ Sci Pollut Res 24:463-475

Oades J (1984) Soil organic matter and structural stability: mechanisms and implications for management. Plant Soil vol. 76, Proceedings of the Conference on Biological Processes and Soil Fertility, pp 319 337

OECD (2008) Environmental performance of agriculture in OECD countries since 1990, 2008. Paris

Olsen S, Sommers L (1982) Phosphorus. In: Page AL et al (ed.) Methods of soil analysis. Part 2, 2nd ed. Agron. Monogr. 9. ASA and SSSA, Madison, WI, pp 403-430

Parvage MM, Ulén B, Eriksson J, Strock J, Kirchmann H (2013) Phosphorus availability in soils amended with wheat residue char. Biol Fertil Soils 49:245-250

Persson L, Bergström L (1991) Drilling method for collection of undisturbed soil monoliths. Soil Sci Soc Am J 55:285-287

Persson I, Klysubun W, Lundberg D (2019) A K-edge P XANES study of phosphorus compounds in solution. J Mol Struct 1179:608-611

R Core Team (2014) R: a language and environment for statistical computing. R. Found. Stat. Comput, Vienna, Austria

Ravel B, Newville M (2005) ATHENA, ARTEMIS, HEPHAESTUS: data analysis for X-ray absorption spectroscopy using IFEFFIT. J Synchrotron Radiat 12:537-541

Rawal A, Joseph SD, Hook JM, Chia CH, Munroe PR, Donne S, Lin Y, Phelan D, Mitchell DRG, Pace B, Horvat J, Webber JBW (2016) Mineral-biochar composites: molecular structure and porosity. Environ Sci Technol 50:7706-7714

Riddle M, Cederlund H, Schmieder F, Bergström L (2018) Magnetitecoated biochar as a soil phosphate filter: from laboratory to field lysimeter. Geoderma 327:45-54

Riddle M, Bergström L, Condron L, Kirchmann H, Schmieder F, Aronsson H (2018a) Phosphorus leaching from an organic and a mineral arable soil in a rainfall simulation study. J Environ Qual 47:487-495
Salomão R, Arruda CC, Souza ADV, Fernandes L (2014) Novel insights into $\mathrm{MgO}$ hydroxylation: effects of testing temperature, samples' volume and solid load. Ceram Int 40:14809-14815

Schmieder F, Bergström L, Riddle M, Gustafsson J-P, Klysubun W, Zehetner F, Condron LM, Kirchmann H (2018) Phosphorus speciation in a long-term manure-amended soil profile-evidence from wet chemical extraction, 31P-NMR and P K-edge XANES spectroscopy. Geoderma 322:19-27

Schwärzel K, Renger M, Sauerbrey R, Wessolek G (2002) Soil physical characteristics of peat soils. J Plant Nutr Soil Sci 165:479-486

Schwertmann U (1964) Differenzierung der Eisenoxide des Bodens durch Extraktion mit Ammoniumoxalat-Lösung. Z Pflanzenernährung Düngung Bodenk 105:194-202

Shenker M, Seitelbach S, Brand S, Haim A, Litaor MI (2005) Redox reactions and phosphorus release in re-flooded soils of an altered wetland. Eur J Soil Sci 56:515-525

Shepherd JG, Joseph S, Sohi SP, Heal KV (2017) Biochar and enhanced phosphate capture: mapping mechanisms to functional properties. Chemosphere 179:57-74

Simard RR, Beauchemin S, Haygarth PM (2000) Potential for preferential pathways of phosphorus transport. J Environ Qual 29:97-105

Simmonds BM, McDowell RW, Condron LM, Jowett T (2015) Potential phosphorus losses from organic and podzol soils: prediction and the influence of soil physico-chemical properties and management. N Z J Agric Res 8:170-180

Sizmur T, Fresno T, Akgül G, Frost H, Moreno-Jiménez E (2017) Biochar modification to enhance sorption of inorganics from water. Special issue on biochar: production, characterization and applicationsbeyond soil applications. Bioresour Technol 246:34-47

Stamm C, Flühler H, Gächter R, Leuenberger J, Wunderli H (1998) Preferential transport of phosphorus in drained grassland soils. J Environ Qual 27:515-522

Takaya CA, Fletcher LA, Singh S, Okwuosa UC, Ross AB (2016) Recovery of phosphate with chemically modified biochars. J Environ Chem Eng 4:1156-1165

Ulén B (2004) Size and settling velocities of phosphorus-containing particles in water from agricultural drains. Water Air Soil Pollut 157: 331-343

Ulén B, Stenberg M, Wesström I (2016) Use of a flashiness index to predict phosphorus losses from subsurface drains on a Swedish farm with clay soils. J Hydrol 533:581-590

Xu K, Zhang C, Dou X, Ma W, Wang C (2017) Optimizing the modification of wood waste biochar via metal oxides to remove and recover phosphate from human urine. Environ Geochem Health. https:// doi.org/10.1007/s10653-017-9986-6

Yao Y, Gao B, Zhang M, Inyang M, Zimmerman AR (2012) Effect of biochar amendment on sorption and leaching of nitrate, ammonium, and phosphate in a sandy soil. Chemosphere 89:1467-1471

Zhang M, Gao B, Yao Y, Xue Y, Inyang M (2012) Synthesis of porous $\mathrm{MgO}$-biochar nanocomposites for removal of phosphate and nitrate from aqueous solutions. Chem Eng J 210:26-32

Zimmermann U, Munnich K., Roether W (1967) Downward movement of soil moisture traced by means of hydrogen isotopes. In: Glenn ES (ed) Isotope techniques in the hydrologic cycle. AM Geophys Union, Geophys Monogr. 11, pp 28-36 